HIV/STD transmission in gold-mining areas of Bolívar State, Venezuela: Interventions for diagnosis, treatment, and prevention

\author{
Lily Faas, ${ }^{1,2}$ \\ Alexis Rodríguez-Acosta, ${ }^{2}$ and \\ Gloria Echeverría de Pérez ${ }^{3}$
}

The gold-mining areas of Bolívar State in Venezuela are characterized by social, economic, and cultural factors that may facilitate transmission of HIV and other sexually transmitted diseases (HIV/STDs). For instance, gold-mining sites tend to have high concentrations of men between the ages of 20 and 45. They serve as a magnet for female commercial sex workers (FCSWs), especially if education and employment opportunities for girls and women are limited. High rates of STDs have been found among FCSWs in the gold-mining areas of Bolívar State, possibly indicative of the lack of power these sex workers have to enforce safe sexual practices with their clients (1-3).

Various publications on the gold-mining areas in Bolivar State have mentioned a sharp rise in violence and alcohol and drug abuse (4), which are directly linked to the practice of unsafe sex. In such a context, transmission of HIV/STDs is more likely $(3,5,6)$.

There are reasons to believe that gold-mining sites may also be characterized by what is called "situational bisexual and/or homosexual behavior." Many men never settle down, migrating out of a particular community once all the gold there has been extracted. These mining sites have their own social organization, with a private system of law and order. These are predominantly male societies, with few women present. Same-sex contacts between men are likely to occur, with a high probability of anal intercourse, which, even with the use of a condom, increases the risk of HIV/STD transmission $(1,3)$.

The incidence of STDs among indigenous populations in gold-mining areas of Bolívar State is on the rise. There is sexual interaction among members of different Indian communities, between mine workers and female members of Indian communities, and between FCSWs and Indian males. Containing the spread of STDs and preventing HIV infection in these populations is hindered by several factors. Besides the overall social, economic, and cultural context, native populations also struggle with a lack of knowledge and understanding of sexuality and sexual behavior; language problems; and limited access to health care facilities and health care workers in the dominant, Creole culture $(3,5,7)$. In addition, the budget for HIV/STD detection and prevention in gold-mining areas is limited or nonexistent due to the presence of other infectious 
diseases often considered more serious, such as malaria and leishmaniasis $(4,8)$. As a result, at the end of 1994, when the HIV epidemic in Venezuela was already well under way, no comprehensive education plan directed at preventing the transmission of HIV and other STDs existed in the goldmining areas of Venezuela's Bolívar State $(2,5,9)$.

From 1995 through the end of 1996, a Caracasbased nongovernmental organization (NGO), Contrasida ("Against AIDS"), developed and implemented an HIV/STD prevention plan covering the various populations living in and around four communities in the heart of Bolívar State's gold-mining region: El Callao, Tumeremo, El Dorado, and Las Claritas (also know as "Km 85," its distance from El Dorado). (For brevity, this gold-mining region will be referred to as the "El Callao-Las Claritas area"; Tumeremo and El Dorado are located between those two communities.) And since epidemiological data on HIV/STDs in this area were scant and incomplete, in October 1996 the NGO carried out a prevalence study to help in formulating a responsible, balanced, long-term health care intervention plan focused on HIV/STD control. Supporting Contrasida in all these activities was the Immunochemistry Section of the Tropical Medicine Institute and the Institute of Immunology, which are both departments of the Central University of Venezuela, as well as the AIDS/STD division of the Ministry of Health of Venezuela.

There are currently more then 50 operating gold-mining sites in Bolívar State. Contrasida chose to focus its intervention efforts on the region around El Callao, Tumeremo, El Dorado, and Las Claritas for a number of reasons. The area is in a transition phase, with gold mining moving from individual and cooperative mining to industrial mining. So far, only a joint venture between a Canadian company, Placer Dome, and a Venezuelan heavyindustry firm, the Venezuelan Corporation of Guyana, has moved beyond the exploration phase in the area. But since industrial mining will be the rule in Bolívar State sooner or later, the experiences of this part of the state may serve as an indicator of future trends $(10,11)$.

The El Callao-Las Claritas region is of great economic importance to Venezuela. Its enormous gold reserves are estimated at more than \$US 4 billion and thus could boost the country's troubled economy. Furthermore, because of the gold-mining activities, border trade with Brazil has expanded, with revenues from sales of cement, trucks, food, and other products growing from $\$ 900$ million in 1993 to $\$ 2$ billion by the end of 1995 , and the upward trend is continuing (12).

The El Callao-Las Claritas area has rapidly developed into an industrialized zone that is attrac- tive to young male migrant laborers, merchants, and FCSWs. Also drawn to the region are such indigenous populations as the Pemon and Arawak, who have turned away from traditional economic activities and become gold miners. The population of the area has grown to include tens of thousands of miners and other persons, and they are often involved in violent conflicts over land, commerce, and women. There are some 500 industrial miners, around 25000 independent miners, and many of the estimated 30000 miners who have entered Bolívar State illegally from Brazil. Other groups include some 1000 merchants; between 500 and 1000 FCSWs, from Venezuela, Colombia, Brazil, and the Dominican Republic; and around 1000 army and police officials. Notable among the Indian communities are the Pemon, with some 100 families in Las Claritas, 750 members in the $\mathrm{Km} 74$ community, and 1000 in the $\mathrm{Km} 33$ community $(2,6,11,12)$.

Records of STD clinics in this area indicate that each week an average of $25-30 \%$ of all individuals seeking counseling test positive for at least one STD. There are also indications that deaths occur due to drug overdoses $(2,5,6)$. While population growth and economic development have been substantial, health care facilities and sanitary provisions have lagged behind. This has complicated diagnosis, treatment, and prevention of diarrhea, malaria, respiratory diseases, and especially HIV/ STDs. To achieve sustained economic development in this area and thus benefit Venezuela as a whole, a healthy population is imperative (11).

\section{Prevention workshops}

From June 1995 through February 1996 the first series of workshops on the issue of HIV/STDs was conducted. In 50 workshops a total of 2000 people in the El Callao-Las Claritas area received an average of one and a half hours of information on HIV/STDs. A flip chart designed by Contrasida was used to explain symptoms of HIV/STDs, modes of transmission, and such ways of preventing transmission as the male and female condom. Since it is impossible to talk about HIV/STDs without talking about sexuality and sex, considerable time was spent on topics like HIV/STDs and heterosexuality, homosexuality, and bisexuality; the risk of HIV/STD infection for women and adolescents in particular; and high- and low-risk sexual behavior in general.

Participants in the workshops were people directly or indirectly involved in gold-mining activities. These included industrial and independent mine workers, merchants, FCSWs, health care workers, teachers and students of primary and sec- 
ondary schools, members of the army and police forces, leaders and members of neighborhood associations, and leaders and members of indigenous communities.

The objective of the workshops was to communicate with the various populations living in the El Callao-Las Claritas area and sensitize them to the problem of HIV and other STDs. All participants received five latex condoms as well as booklets and brochures on HIV/STDs and their prevention. At the same time, the workshops generated valuable information on the participants' knowledge, attitudes, and practices concerning HIV/STDs. This information was supplemented by data from evaluation sheets that workshop participants filled out (3).

\section{High-risk and low-risk sexual behaviors}

In all the social groups participating in the prevention workshops, sexual behaviors facilitating STD/HIV transmission were found. More than $60 \%$ of the individuals did not know how HIV was transmitted, and $90 \%$ said they had never seen or used a condom. Of the workshop participants, $70 \%$ of the adult males and $60 \%$ of the adult females considered anal sex to be an effective contraceptive method and thus did not perceive it as an unsafe sex practice. Alcohol intake among miners and FCSWs averaged at least five drinks daily, and more than $15 \%$ of these groups said they knew someone who used drugs, particularly "crack" cocaine.

Some 500 members of indigenous communities participated in the Contrasida workshops. The educational material used for these groups, notably Pemon and Arawak Indians, was quite different in style from the materials used with miners, FCSWs, and members of the army. The material was less direct, leaving an opportunity to expand on or withhold issues like sexual orientation and high-risk sexual behavior, according to the prevailing atmosphere in the group. Some Indian chiefs had said that people might take offense at a demonstration of how to use a condom and that they might see it as a form of exploitation or a scheme to swindle them and increase the sales of condoms. So in the workshops, which had been approved by the chiefs, Contrasida personnel always took great care to repeat time and again the importance of a mutually monogamous relationship and the value of love, respect, and responsibility in the fight against HIV/STDs. Condoms were merely presented as a solution for those people who did not find themselves in such fortunate circumstances. At the same time, Contrasida tried to place the use of a condom in a broader context, such as by presenting it as a possible method of family planning (3).
Members of the indigenous groups generally had limited knowledge of HIV/STDs, but most had heard of gonorrhea and syphilis. Many indigenous women wanted to know if contraceptive pills or vaginal irrigation would protect them from HIV/ STDs. Some male members said using condoms would promote homosexuality in the community. Many people paid close attention during the workshop explanation of high- and low-risk sexual behavior. Despite the chiefs' fears about people possibly being offended, young and old seemed to enjoy the demonstration of how to use a condom. Some condoms were passed around so that people could touch and stretch them. This led to great laughter and jokes. Most members seemed to have a pragmatic attitude towards Creole influence on their lives, and they have not taken special steps to prevent this influence from happening. In the workshops they were open to discussing sex and sexuality, and they expressed such perceived needs as family planning. Individuals clearly felt free to either accept or not accept the condoms offered to them. As the workshops ended most people lined up to receive condoms. Others thanked the Contrasida personnel but said they couldn't accept the condoms because of their Seventh Day Adventist religious beliefs (3).

\section{Prevalence study}

The HIV/STD prevalence study was carried out in the second week of October 1996, in cooperation with the Institute of Immunology of the Central University of Venezuela, the Ministry of Health, and local Tumeremo health authorities. The Embassy of Canada in Caracas financed a considerable part of the operation. Various health markers were included in the study, notably HIV, syphilis, hepatitis $B$ virus (HBV), and human t-lymphotropic virus types I and II (HTLV I/II) $(13,14)$. The diagnostic company Organon Teknika (parent firm, Akzo Nobel) provided most of the various reagents used in this study.

The first week of October Contrasida personnel began encouraging the various populations in the gold-mining area to participate in voluntary and confidential testing. Community leaders as well as local health care institutions pledged their support to the project and were involved throughout the operation. Posters and leaflets inviting people to participate were distributed in all the villages, bars, brothels, and other locations as well. The day before testing was to be done in each of the various communities, a megaphone was used to repeat and reinforce the invitation to participate. 
For the epidemiological study, Contrasida personnel attempted to include a representative sampling of persons from all the various sexually active populations in the gold-mining areas, but that task was made difficult by the lack of comprehensive, reliable demographic data for the region and obstacles in contacting many men digging gold at isolated sites. Blood samples were analyzed for 893 individuals, all of whom signed a letter of informed consent. Of the participants, $62.6 \%$ were female and $37.4 \%$ male. The age group of $25-45$ years old comprised $54 \%$ of the persons sampled, followed by the group 14-25 years of age, which represented $32 \%$ of the total sample. Those 45 years and older represented $11.5 \%$ of the sample. A few youngsters between 11 and 13 years old who said they were sexually active were also included. They represented $2.5 \%$ of the sample, and STDs were not found in this group. Almost $26 \%$ of all participants were permanent residents of the gold-mining area, $2.8 \%$ of the sample were Colombian nationals, and $5 \%$ came from the Dominican Republic. Nationals from Trinidad-and even the African country of Ghana-made up fewer than $1 \%$ of the participants. The remaining $65 \%$ were Venezuelans who had come from outside Bolívar State. Table 1 shows the categories of participants.

Sera were screened for antibodies against HIV and HTLV I/II by enzyme immunoassay (EIA), and double reactive specimens were confirmed by Western blot for HIV and both Western blot and immunofluorescence for HTLV I/II. For syphilis a specific hemagglutination method was used, and for HBV a high-sensitivity MicroELISA test was applied.

The prevalence study participants received packages containing condoms and a brochure on contraception. They also received two HIV/STD prevention pieces designed and printed by Contrasida, a brochure entitled "Amor en el tiempo del SIDA" ["Love in the Time of AIDS"] and a booklet on high- and low-risk sexual behavior called "Sexo seguro en la era del SIDA" ["Safe Sex in the AIDS Era"]. In addition, all participants received vials with vitamin B tablets to improve their general health. Malaria is highly endemic in the gold-mining area. When administered in high doses vitamin B produces a skin odor that deters mosquitoes and thus diminishes the probability of malaria infection from mosquito bites. Because the minimal body care shown by women in the area may indicate low selfesteem - which would make it harder for them to assert themselves and insist on safe-sex practicesparticipating women were also given body care products as a step toward boosting their self-respect.

The logistics for the prevalence study were challenging. The area is poorly equipped as far as laboratory and waste disposal facilities are con-
TABLE 1. Categories of persons in HIV/STD prevalence study, Bolívar State, Venezuela, October 1996

\begin{tabular}{lcr}
\hline \multicolumn{1}{c}{ Category } & Number & $\%$ \\
\hline Mine workers & 189 & 21.1 \\
Gold-mill owners/gold transporters/ & & \\
gold merchants & 71 & 8.0 \\
Female commercial sex workers & 88 & 9.9 \\
Housewives & 154 & 17.2 \\
Pemon and Arawak Indians & 218 & 24.4 \\
Students & 23 & 2.6 \\
Hospital personnel & 60 & 6.7 \\
Other (e.g., soldiers, hairdressers, and & & \\
teachers) & 90 & 10.1 \\
$\quad$ Totals & 893 & 100 \\
\hline
\end{tabular}

cerned. Consequently, Contrasida had to bring all the equipment for testing from Caracas, $1000 \mathrm{~km}$ away. This included not only syringes, needles, cotton, alcohol, and sterile gloves but also centrifuges and a refrigerator. The only way to get rid of biological waste was by incinerating it. Due to a short circuit in the refrigerator, Contrasida lost all 102 blood samples taken from the Pemon indigenous community at San Miguel de Betania (Km 67). This happened on the first day of testing and utterly demoralized the Contrasida team, who were afraid other communities would decide not to participate. However, only one community did so.

On the seventh day of the operation the remaining 893 blood samples were flown from Puerto Ordaz to the Institute of Immunology in Caracas. There, a team of experts processed all the samples in less than a month and at no charge. In December three members of the Contrasida team made another trip to the gold-mining area, to inform the participants of the results and to offer treatment free of charge for those who tested positive for syphilis.

Table 2 shows the prevalence of STDs in the various gold-mining communities. Out of the 893 individuals tested, 178 (19.6\%) of them had either one or two STDs. Contrasida found STDs among persons ranging in age from 14 to 80 years old and in all the various social groups, including miners, housewives, FCSWs, health care personnel, and members of indigenous communities. The only exceptions were the small number of youngsters between 11 and 13 years old who were surveyed, and the Arawak community at San Flaviano ( $\mathrm{Km} \mathrm{47).}$ Some Arawak communities have migrated to Venezuela from Guyana. Their members speak English and as of yet don't seem to have mingled sexually with the Creoles or with other Amerindian groups in the gold-mining area. They search for gold in rather isolated locations towards the border with Guyana. These factors might explain the lack 
TABLE 2. Number of persons with one or two STDs, Bolívar State, Venezuela, October 1996

\begin{tabular}{|c|c|c|c|}
\hline & $\begin{array}{l}\text { Number of } \\
\text { participants }\end{array}$ & $\begin{array}{l}\text { Persons with } \\
1 \text { or } 2 \text { STDs (\%) }\end{array}$ & $\begin{array}{l}\text { Number of those } \\
\text { with syphilis (\%) }\end{array}$ \\
\hline \multicolumn{4}{|l|}{ Area: } \\
\hline El Dorado & 223 & $41 \quad(18.4)$ & $35(15.7)$ \\
\hline Las Claritas/Ciudad Dorada area & 213 & $39(18.3)$ & $31 \quad(14.6)$ \\
\hline Las Claritas/Santo Domingo area & 103 & $23(22.3)$ & $23(22.3)$ \\
\hline Tumeremo & 103 & $30(29.1)$ & $26 \quad(25.2)$ \\
\hline El Callao & 35 & $5(14.3)$ & $5(14.3)$ \\
\hline \multicolumn{4}{|l|}{ Indigenous communities: } \\
\hline Pemon: Araimatepui (Km 74) & 87 & $20(22.0)$ & $11(12.6)$ \\
\hline Pemon: Santa Lucia de Inaway (Km 85) & 88 & $16(11.4)$ & $14(15.9)$ \\
\hline Arawak: San Flaviano (Km 47) & 13 & $0 \quad(0.0)$ & $0 \quad(0.0)$ \\
\hline Arawak: Hobochirima (Km 72) & 28 & $4(14.3)$ & $3(10.7)$ \\
\hline Totals & 893 & $178(19.6)$ & $148(16.6)$ \\
\hline
\end{tabular}

of infection in this particular Arawak community $(15,16)$.

Nine persons, or $1 \%$, were found to be positive for HIV. This group included 7 males, as well 2 females who were both barely 20 years old. One of the women was a housewife, and the other was a sex worker. Of the men who tested positive for HIV, 3 were gold miners, 2 were hairdressers, and 1 was a merchant. Finally, 1 member of an indigenous community tested positive for HIV, the first such case to be diagnosed in Venezuela and cause of great concern because it indicates the spread of the epidemic to a new population. Contrasida managed to locate 7 of the persons infected with HIV and counseled them and referred them to the "Ruiz y Paez" Hospital in Puerto Ordaz for follow-up. Interestingly, 2 out of the 7 individuals had used the Contrasida prevalence study as a way to confirm a positive result on an earlier HIV antibody test.

Table 2 further indicates that $148(16.6 \%)$ of the 893 participants were found positive for syphilis. Among person 25-45 years old, 99 cases of syphilis were diagnosed, representing $66.9 \%$ of the total number of syphilis cases found. Furthermore, 5 individuals were infected with both syphilis and HIV.

Among the 148 cases of syphilis were $11 \mathrm{fe}-$ male health care workers, 25 housewives, and 26 FCSWs, with prevalence rates of $20.0 \%, 16.2 \%$, and $29.5 \%$, respectively (Table 3 ). Most housewives, including women from the indigenous communities, said they knew their partners had extramarital sexual contacts, but it never occurred to them to have a medical checkup, or to address the issue of condom use with their partner. On the other hand, several of the participating housewives admitted doing "some sex work" during the time that their partners were working in the mines, and especially if the men did not support them financially.
Female miners had higher prevalence rates than male miners did. Out of the 189 mine workers who participated in the prevalence survey, 44 were women. Of those women, $10(22.9 \%)$ were positive for syphilis. Of the 145 male mine workers "only" 22 $(15.2 \%)$ of them proved to be infected with this disease. Almost all of the men infected said they practiced self-medication when they suspected they had an STD. Medications most used were kanamycin (sold in Venezuela under the trademark Kantrex) and spectinomycin (Trobicin). These can be obtained at any pharmacy in the gold-mining area, without the need for a prescription. Kanamycin and spectinomycin, however, are only effective against gonorrhea. In addition, many of the infected men said they did not inform their partners when they had an STD. Condom use among these men was unpopular.

In addition, 26 participants tested positive for hepatitis $B$, which can be transmitted both by blood and sexual contact. Six of those persons were also infected with syphilis. Contrasida staff advised all the individuals with hepatitis to go to the "Ruiz y Paez" Hospital to have their infection monitored.

TABLE 3. Prevalence of syphilis in various social groups, Bolívar State, Venezuela, October 1996

\begin{tabular}{lrcr}
\hline \multicolumn{1}{c}{ Category } & Total & Positive & $\%$ \\
\hline Gold miners & 189 & 32 & 16.9 \\
FCSWs & 88 & 26 & 29.5 \\
Housewives & 154 & 25 & 16.2 \\
Gold-mill owners/gold & & & \\
$\quad$ transporters/gold merchants & 71 & 14 & 19.7 \\
Health care workers & 60 & 13 & 21.7 \\
Pemon and Arawak Indians & 218 & 29 & 13.3 \\
Others & 113 & 9 & 8.0 \\
$\quad$ Totals & 893 & 148 & 16.6 \\
\hline
\end{tabular}


Finally, another 7 participants tested positive for HTLV I and 3 were positive for HLTV II. HTLV I/II are retroviruses that are primarily transmitted by breast-feeding, although they can also be transmitted sexually and by blood contact. The cases of HTLV II were found only in indigenous communities. This was expected, given the fact that HTLV II is dubbed a "New World virus" endemic to certain indigenous peoples. HTLV II has not been associated with any disease as of yet and the individuals involved were informed as such. The results of the study seem to indicate that HTLV II so far has only marginally penetrated the Amerindian and Creole populations in the gold-mining area. Among other Venezuelan Amerindian populations, notably the Yaruro and the Guahibo, a much higher prevalence of this infection has been noted, $5 \%$ and $25 \%$ respectively (13).

Infection with HTLV I does give reason for concern, since it is associated with T-cell leukemia, as well as with certain types of paralysis. It affects around 3 out of every 1000 inhabitants of Venezuela (17), causing disease in 3 out of 100 of those infected. Contrasida only managed to locate 1 of the 7 infected individuals. This participant was advised to abstain from donating blood, since the Venezuelan blood supply is not checked for either HTLV I or II. Contrasida also suggested she not breast-feed her children and that she use condoms. It should be noted that 3 out of the 7 individuals infected with HTLV I were also positive for syphilis (two women, both sex workers) and hepatitis B (one woman, a health care professional) (17).

\section{Treatment for syphilis}

Various studies have shown treating syphilis and other STDs can help limit the spread of HIV. For those infected with both syphilis and HIV, treatment of syphilis will possibly slow down progression to AIDS and at the same time make these individuals less infectious to others (18). In light of this Contrasida offered treatment for syphilis free of charge to all those prevalence study participants who had tested positive.

Syphilis is the third most common STD in Venezuela, following chlamydia and gonorrhea. Indeed, health care professionals working in the goldmining area stated that gonorrhea is rampant. Several doctors who deliver babies at the Tumeremo hospital commented that almost all women giving birth deliver infants infected with gonorrhea (19).

For logistical reasons it was impossible for Contrasida to include testing for gonorrhea in this HIV/STD effort since that would have required access to a medical setting in order to be able to take vaginal smears from female participants. Because of the large number of individuals who presented themselves, this was simply not feasible. Contrasida did, however, consider offering dual treatment with ceftriaxone and doxycycline for all those individuals positive for syphilis. The idea was to cure both syphilis and gonorrhea at the same time. However, this line of action was too expensive and Contrasida had to accept the more conservative approach of treating syphilis with intramuscular benzathine penicillin G 2.4 million units in one dose. Of the 148 individuals positive for syphilis Contrasida managed to locate 81,61 of whom chose to go for STD treatment provided at the Tumeremo hospital. Some of the individuals positive for syphilis were clear cases of late latent syphilis, with infection having lasted more than a year. Contrasida encountered several individuals 60 years old and two individuals 80 years old who were positive for the disease, all members of indigenous communities. In these cases treatment consisted of intramuscular benzathine penicillin 7.2 million units, administered in three doses of 2.4 million units, given one week apart for three consecutive weeks (19).

In all, Contrasida managed to locate 503 of the 893 prevalence study participants, or $56.3 \%$ of them. This was a far better result than the NGO had expected since around one-third of the residents of the area migrate every two months, generally to somewhere else in Bolívar State. All the individuals who could be located and who had tested negative for HIV and the other health markers included in the study received a letter indicating their status.

\section{Discussion}

The Ministry of Health of Venezuela has estimated that as many as $1 \%$ of the total Venezuelan population, or some 200000 individuals, might be positive for HIV. This $1 \%$ prevalence is the same as the level Contrasida found in the gold-mining area. However, HIV studies conducted in the same area in 1993 found only two persons positive for HIV from a much bigger sample size, compared with the 9 out of 893 found positive in the 1996 Contrasida study. This noticeable increase in HIV prevalence may be due to migration of economically deprived men and women from other parts of Venezuela to the gold-mining area in Bolívar State $(3,19)$.

The small number of FCSWs infected with HIV in the Contrasida sample-only 1 out of 88 follows a pattern seen with Venezuelan national statistics. Out of all the women diagnosed with AIDS in Venezuela, only $4.1 \%$ have been FCSWs, with the rest being female adolescents, professional women, and housewives. Indeed, it seems that for 
Venezuelan women, being married is a risk factor for HIV infection $(20,21)$.

Statistics from the Contrasida study indicate a syphilis prevalence rate in the gold-mining area far above the level found elsewhere in Venezuela. National epidemiological data indicate that syphilis affects 40 individuals out of every 100000 and represents only $8 \%$ of all STDs diagnosed. The Contrasida survey in the gold-mining area found that $16.6 \%$ of the participants were infected with syphilis, with the 148 syphilis cases representing $76.7 \%$ of all the STDs diagnosed $(2,11,19)$.

Persons with syphilis are particularly prone to HIV infection, given the fact that genital ulcers caused by the disease provide an easy entry point for HIV (22). Steps should be taken to deal with this situation in the gold-mining area, such as through active STD treatment and contact tracing.

A special note is warranted on STDs diagnosed in the indigenous groups. In several communities, syphilis was found almost exclusively in siblings, usually adolescents, from the same household. Contrasida personnel who counseled these persons learned that siblings tend to experiment sexually with the same woman or man, usually someone outside their community, and that the young people do not like to use condoms.

While the series of workshops as described in this case study reached some 2000 people, it is still too early to expect any real change in sexual conduct. However, receptivity was good, and in each social group Contrasida has been able to find peer educators and outreach workers. More training for these individuals is imperative for HIV/STD prevention programs in the gold-mining area to be successful, and Contrasida's future interventions will be dedicated to that. Also crucial is implementation of a condom social marketing program.

In these future efforts, one special challenge will be dealing with some officials from the police and National Guard who push for unprotected sexual relations with FCSWs. Women who refuse may lose their health certificate, making it impossible to work, or even worse, they may face imprisonment. In the prevention workshops, Contrasida personnel raised this issue and emphasized the officials' responsibility to prevent HIV/STD infection of their families, especially their wives, and the message was well taken $(3,5)$.

Acknowledgements. We wish to thank the Canadian Embassy in Caracas, as well as the Embassy of the Netherlands, for their continuing support of the HIV/STD prevention project in the gold-mining area. Special thanks also to Dr. A. Caraballo, former Director of Investigation of Endemic Diseases of the "Dr. José Gregorio Hernández" Hospital in Tumeremo, for his sound and professional advice throughout the project. We express our gratitude to the Institute of Immunology of the Central University of Venezuela for processing the blood samples. Special thanks also go to the executive personnel of Placer Dome for their moral and financial support. Contrasida thanks all the community leaders in the gold-mining area for their wholehearted support. Lastly, we thank Dr. Yon Fleerackers of the Tropical Institute of Antwerp for his support in designing the epidemiological study.

\section{SINOPSIS}

\section{Transmisión de VIH/ETS en zonas de explotación minera de oro en el estado de Bolívar, Venezuela: intervenciones con fines de diagnóstico, tratamiento y prevención}

En este trabajo se presenta la implementación de una serie de talleres sobre la prevención de la infección por VIH y otra enfermedades de transmisión sexual (ETS) para beneficio de diversas poblaciones de habitantes del territorio con minas de oro que comprende El Callao, Tumeremo, El Dorado y Las Claritas, en el estado de Bolívar, Venezuela, y también un estudio de prevalencia que se realizó en la misma población. Atraídos por las oportunidades económicas, millares de hombres jóvenes han migrado a esa zona y su presencia en ella ha atraído, al mismo tiempo, a muchas trabajadoras sexuales. La situación, sumada a otros factores sociales, económicos y culturales, facilita la propagación de la infección por VIH y de otras ETS en el territorio.

Más de 2000 personas asistieron a los talleres sobre la prevención de la infección por VIH/ETS, que también se aprovecharon para reunir información sobre las prácticas sexuales en la zona minera. El estudio reveló prácticas sexuales de alto riesgo en todos los grupos estudiados. Antes de este proyecto de investigación se disponía de información epidemiológica escasa e incompleta sobre las infeccions por VIH/ETS en esa zona. Para el presente estudio se tomaron 893 muestras de sangre de habitantes de la localidad. Las pruebas realizadas revelaron una altísima frecuencia de infección sifilitica y de infección por VIH, virus de la hepatitis $B$ y virus humanos linfotrópicos $\mathrm{t}$ de tipos I y II. Los resultados de los tallers sobre prevención y del estudio epidemiológico se usarán para crear un plan bien dirigido a largo plazo para la prevención de VIH/ETS en la zona de explotación minera de oro. 


\section{REFERENCES}

1. Faas L. Zonas mineras Venezolanas y el VIH-SIDA. VIH-SIDA: Organo Divulgativo de la División SIDA/ETS, Ministerio de Sanidad y Asistencia Social 1996;5:12-13.

2. Acuña M, Rosal F. Diagnóstico de salud de Las Claritas [mimeo]. Ciudad Bolívar, Venezuela: Universidad de Oriente, Nucleo Bolívar, Escuela de Medicina, Medicina Preventiva y Social; 1994.

3. Faas L. First description of STD/ HIV related risk factors in gold-mining areas of Tumeremo-El Dorado and Las Claritas, Bolivar State, Venezuela [mimeo]. Caracas, Venezuela: Institute of Immunology, Universidad Central de Venezuela; 1995.

4. Rodriguez-Acosta A. Un asunto de salud en Amazonas. In: Taller metodológico regional: Minería y salud. Evaluación de sus impactos en la salud ambiental en Amazonia [mimeo]. Asociación de Universidades Amazónicas, Centro Internacional de Investigaciones para el Desarrollo, United Nations Educational, Scientific, and Cultural Organization, Universidad de los Andes de Colombia; 1994.

5. Faas L, Narvaez B. HIV/STD transmission in gold-mining areas of Venezuela: An example of successful co-operation between the government and NGO's [poster presentation]. Vancouver, Canada: XIth World AIDS Conference, 1996.

6. Casanova I. Por una pepa de oro: Testimonios de las minas de oro de Guayana. 1st ed. Upata, Venezuela: Predios Narrativa; 1994
7. Barreto D. Hacia una utopia en la región amazónica. ¿Investigaciónaprendizaje-acción en el campo de salud? In: Yarzabal L, Espinal C, Aragón, LE, eds. Enfoque integral de la salud humana en la Amazonia. Caracas, Venezuela: Asociación de Universidades Amazónicas; 1992:457-477.

8. Gamboa de Dominguez N, Rodríguez-Acosta A. Glutamate dehydrogenase antigen detection in Plasmodium falciparum infections. Korean I Parasitol 1996 Dec;34(4):239-246.

9. Rodríguez-Ochoa G. Situación de salud en el Territorio Federal Amazonas, Venezuela. In: Yarzabal L, Espinal C, Aragón LE, eds. Enfoque integral de la salud humana en la Amazonia. Caracas, Venezuela: Asociación de Universidades Amazónicas;1992:407-429.

10. Wade J. All is not gold. Business Venezuela 1994 July;165:14-18.

11. Centro de Estudios del DesarrolloUniversidad Central de Venezuela. Proyecto evaluación de impactos en salud y ambiente en la Amazonia: Informe de actividades, 1994-1995 [mimeo]. Caracas, Venezuela: CENDES-UCV; 1995.

12. Wilson P. No bust this time. Business Venezuela 1994 July;165:26-30.

13. Echeverría G, León-Ponte M. First description of endemic HTLV-II infection among Venezuelan Amerindians. I Acquir Immune Defic Syndr 1993 Dec;6(12):1368-1372.

14. Machado I, Deibis L, Risquez E, Tassinari P, Zabaleta M, Toro F, et al. Abordaje inmunoclínico, molecular e inmunopatológico de la hepatitis crónica viral. Consideraciones terapeúticas. GEN 1994;48:124-132.

15. Forte J. Thinking about Amerindians. 1st ed. Georgetown, Guyana: Business Print; 1996.

16. Forte J, Melville I. Amerindian testimonies. 1st ed. Georgetown, Guyana: Business Print; 1989.

17. Echeverría G, et al. Reappraisal of human retroviral infection in Venezuela. AIDS Res Hum Retroviruses 1992 Feb;8(2):219-220.

18. Dallabetta G, Laga M, Lamptey P, eds. Control of sexually transmitted diseases: A handbook for the design and management of programs. Arlington, Virginia, United States of America: AIDS Control and Prevention Project/ Family Health International; 1996.

19. Ministerio de Sanidad y Asistencia Social, Dirección Técnica de Programas de División SIDA-E.T.S. Vigilancia epidemiológica del SIDA Venezuela, 1982-1997. Caracas, Venezuela: MSAS; 1997.

20. Pérez-Silva M. Investigation on gender information and knowledge on HIV/STD's of commercial sex workers' adolescent daughters [poster presentation]. Vancouver, Canada, XIth World AIDS Conference, 1996.

21. Programa Conjunto de las Naciones Unidas sobre el VIH/SIDA. El VIH/ SIDA en Venezuela: Análisis de situación y recomendaciones. Caracas, Venezuela: ONUSIDA; 1998.

22. Hoffman J. Effects of urethritis therapy on the concentration of HIV-1 in seminal plasma [presentation]. Vancouver, Canada; XIth World AIDS Conference, 1996. 